\title{
Participation in Culture of Adults with Moderate Intellectual Disabilities: Biographical Analysis of People Living with their Parents
}

\begin{abstract}
This paper discusses issues related to the participation in culture of adults with moderate intellectual disabilities. The aim of this paper is to present the findings of a study interpreting and constructing participation in culture by members of this group. I was interested in how such people experience culture and how they interpret it and what significance they attach to its various manifestations. This piece of research was located in the current of constructivist and interpretative studies, which has enabled the application of the biographical method. The research project used four individual, in-depth and partially structured interviews and narrative analysis.

The narratives told by the interviewees reveal the subjective sense and meaning imparted by people with intellectual disabilities to their own participation in culture. The narratives have shown the difficult adulthood and the resulting problems of everyday life. The biographies of adults with intellectual disabilities living with their parents show the complexity of adulthood and the resulting attributes. Due to the difficulties of everyday life, the reality constructed by the narrators is filled with regret, anger, disappointment, sadness and longing for normality. Negative emotions do not allow them to develop, to open up to people, to build relations with them. This results in a limited participation of adults with intellectual disabilities in culture in a broad sense of the word.
\end{abstract}

\section{Keywords:}

culture, family, intellectual disability, adulthood, qualitative research

Department of Special Education, Faculty of Social Sciences, University of Warmia and Mazury in Olsztyn, Poland, E-MAIL: iwona.mysliwczyk@uwm.edu.pl. 


\section{INTRODUCTION TO CULTURE AND FAMILY}

With the title in mind, one should make a reference to two issues: culture and family, and in particular, a family with an adult child with intellectual disabilities. These categories make up the notional framework for this study and, importantly, both the family and culture make a natural environment of a person, in which he/she "continuously produces, acquires, records and transfers cultural values on the basis of his/her own experience" (Kwiatkowska \& Siudem, 2014, p. 7). The importance of the family in culture is paramount, because man is mainly educated in line with the culture represented by the family and only then does he submit to its other influences (Molesztak, 2015, p. 7), because - as M. Fleischer points out - "we constantly feel the presence of and are confronted with culture" (2002, p. 19).

Culture is an ambiguous term. There are various approaches to it and its heterogeneous definitional interpretation, and this ambiguity - according to Z. Bauman - results not from various ways in which culture is defined, but from "incompatibility of cultural traditions" (Bauman, 2012, p. 92). The multitude of definitions is indicative of the deep interest of researchers in the term "culture"; in consequence, it is not possible to address in this study all the fields of research in which this category is considered. A. Giddens presents a broad meaning of "culture", denoting art, literature, painting, music, film, which means "supreme products of the mind" (2012, p. 45). Therefore, one participates in culture when one listens to music, uses the Internet or watches programmes on TV, which are not only entertaining, but which tell a story about ourselves (Godzic, 2013, pp. 28-29). In this manner - that is, by commenting on our world - they describe the constantly changing patterns of culture (Jakubowski, 2017, p. 10). Therefore, culture is "a set of diverse standards which regulate ways in which an individual participates in culture, they enable interpreting the sense of cultural objects and actions and they enable one to embrace mentally the reality, which a society defines in terms of the concepts. [...] Cultural knowledge is perceived as deduced from experience, resulting from a combination of basic distinctive features of the perceived world. In this sense, an individual is a learner of culture, which means that he represents his own variety of culture, encompassing only certain aspects of it” (Kwiatkowska \& Siudem, 2014, p. 7).

Culture is attributed to society and not to the individual, which means that it shapes and structures the social life. Therefore, the term "culture" includes people's way of life, their family, religious, professional lives as well as the way they dress, how they spend their free time (Giddens, 2012, p. 45). The term is interpreted in 
the same way by P. Sztompka, who writes that culture is "a comprehensive way of life typical of a community, which comprises everything people do, think and have as members of the society (patterns of action, thinking and material possessions)" (2002, p. 255). Therefore, culture is everything that man learns during his life and what he passes on through generations (Gruchoła, 2010, p. 98). The importance of "the social legacy of members of the society" is emphasised by N. Goodman, who write that culture is "conscious legacy of products, knowledge, values and normative expectations, passed on within the society, which helps members of the society to cope with emerging problems” (1997, p. 37). A similar approach to culture is presented by M. Gruchoła, who writes that culture "originates and develops as a result of contacts between individuals who exchange information and learn from one another how to react and behave in various situations” (2010, p. 105).

Existing in the world, man accepts certain codes of verbal and non-verbal signs, which serve his communication with the environment. By participating in culture, he creates his cultural image and his identity (Molesztak, 2015, p. 11). Cultural goods - writes K. Pankowska - broaden a person's mind and introduce them to the world of values. They thus create "the real understanding of life", thereby shaping the man's personality. By interpretation of cultural goods, i.e., "objectified forms of human spirit”, the nature of man can be explored (Pankowska, 2013, p. 39). Culture also aims: "to improve the existence of man and the world around him; what man does and dreams of in the context of his own development and the development of mankind; what facilitates this development and becomes a school of richer humanity. By participating in reality, marked by cultural factors, man has the opportunity to communicate socially and to value phenomena, and contact with cultural products and the world of values guarantees to shape his personality” (Kwiatkowska \& Siudem, 2014, p. 7).

Thus, human participation in culture is seen as any contact with cultural products and behaviours. This involves direct or indirect contact with other people and consists in "using cultural products, assimilation, processing and restoration of the values inherent in them, submitting to cultural patterns, but also creating new products, values and behaviours” (Golka, 2008, p. 122).

Participation in culture, according to J. Lach-Rosocha, forces us to anchor on a foundation that would be permanent and common for all and to shape our personal identity on the basis of values and patterns that this foundation postulates. The author points out that this must be based on a culture which, "while separating itself from the world of nature and disregarding its laws, places certain requirements on man. [...] Culture [...] gives man a perspective for development that goes far beyond his natural needs, thus enabling him to find his place in the world, to 
define his relations with other people, that is, to give his personal life a sense and a supra-individual meaning. Thus, it obliges him not only to make an effort to be a man, but also to become fully himself” (2006, pp. 97-98).

These words show that man would not be able to build his identity outside of culture, to construct it from his personal experience, which always reflects the specificity of the situations experienced. In other words, we "construct our identity in contact with culture, regardless of its «levels»" (Jakubowski, 2017, p. 10). No man could develop outside culture (Szczurek-Boruta, 2006, p. 158), because culture is produced and absorbed by people. It is particularly important for the mental development of human beings, because it is a force that co-creates them, which means that individuals must learn to negotiate their own existence with culture (Konarzewski, 1994, p. 368).

One can quote a multitude of definitions of culture, showing the multiplicity of its perspectives and types. One can write a lot about culture, because its etymology and significance have made it a common category both in the field of science and in public life. However, the restricted framework of this study allows me only to signal the importance of this category in social sciences.

Another important issue, in the context of the reflections, is the family. Family issues, as well as culture, are also discussed by representatives of various scientific disciplines. Research focuses, among other things, on models of family life, a system of values cultivated by the family, its structure and roles played within it. However, the term "family" is also used in everyday language and the practice of social life (Jabłoński \& Ostasz, 2001). The essence of this basic cell of social life is considered in various dimensions, which should make it understandable. Unfortunately, as S. Kawula points out, "the phenomenon of the family cannot be directly and easily translated into social practice" (2009, p. 363). This is due to the fact that the family, as an object of scientific interest, has a distinctly "multidisciplinary colouring” (Kawula, 2009, p. 363).

An important element of analysis of the essence and functioning of a family is the psychosocial context, i.e., quality of life, communication, interpersonal relations, ties, personality and emotional factors, everyday functioning (OstrouchKamińska, 2015, p. 32). This indicates that the family is a complex construct, but definitely more complicated is a family with a disabled child, because - according to the study by H. Borzyszkowska - "attitudes similar to those shown to people with disabilities are also shown to their families" (1997, p. 31). This means that "to some extent, the stigma carried by a person also places a certain burden on those associated with him/her in the social structure” (Świtaj, 2008, p. 17). This may be due to the transformation of a family status in connection with the care for 
children with disabilities, i.e., the differences in parental roles taken up (Wiatr, 2008, pp. 71-72). Being a parent of a child with intellectual disabilities makes the parents - according to A. Giddens - face an existential challenge. The author writes:

When, for some reason, the routine is broken [...], this may lead to an existential crisis. An individual may feel a particular lack in watershed moments, because it is then that moral and existential dilemmas become the most intense. An individual stands face to face with what has been fended off, but may lack mental and social resources to cope with such issues (2002, p. 229).

In a complex family situation, there is a noticeable "strangeness" of the family, which is brought up as a social issue, whereas the parental issues, which affect its functions, are disregarded. The hardships of parents with a disabled child, which are a great burden for them and for the whole family, are ignored, because "apart from internal, emotional issues, there is a lot of burden associated with the treatment and expenses, rehabilitation, extended period of care [...]. In cases of severe disability, parents do not have a time off throughout their entire lives [...]" (Kościelska, 2003, p. 27).

Parents caring for their disabled adult offspring are becoming increasingly visible in society (Wrona, 2016, p. 214). This is a consequence of medical progress, better social or therapeutic care, which extends the lifespan of people with disabilities. It requires parents to be prepared for a variety of activities "which will support them in the implementation of childcare and education measures aimed at their adult children with disabilities” (Wrona, 2016, p. 214). Unfortunately, the participation of adults in family life is limited due to parents' attitudes towards a disabled adult child. A. Krause writes about infantilisation in this respect, resulting from it being difficult for parents to accept and satisfy the needs of an adolescent child (2010, p. 122). An additional difficulty is the lack of social support in obtaining independence by disabled youth and the society's expectations from the parents. These expectations force parental protectiveness, care and assistance throughout the child's life, including adulthood. In such cases, achieving adulthood - as A. Krause stresses - will be made difficult not only by the attitude of parents but also by the expectations of the society (2010, p. 122).

Adulthood of people with intellectual disabilities is also limited by barriers "resulting from the limitations of social competences necessary to properly perform various roles in society. Lack of both appropriate aspirations and competence - it somehow restricts disabled people in their social development, and thus in the process of becoming grown up and mature” (Ostrowska, 2003, p. 52). The author 
of these words believes that this is the result of inappropriate socialisation carried out in a family environment, where the closest relatives, fearing possible failures, promote the minimalistic perspective of life. It contributes to limiting goals and, in a longer perspective, to the incapacitation and helplessness of people with disabilities. The consequence of this is that adults with disabilities are treated like children (Ostrowska, 2003, p. 52).

When analysing the situation of people with intellectual disabilities, we emphasize the importance of a rehabilitation environment, which should not allow but rather create opportunities for a person with intellectual disabilities to function in the roles of an adult. Through this practice, adult people with intellectual disabilities have optimal conditions for gaining experience that promotes proper functioning in their immediate social environment. This means that this group of adults are able to function as adults, and hence are able to live a dignified life in their immediate neighbourhood and to take up respected social roles arising from adulthood (Źółkowska, 2003, p. 251). However, it is worrying that the society treats people with intellectual disabilities similarly to other social groups regarded as deviating from socially respected and recognised norms. According to B. Cytowska, it is a great misunderstanding because "the problems experienced by this population make its social perception much worse” (2012, p. 117). Therefore, it is becoming important to integrate and normalize the living conditions of adults with disabilities, which will never work properly if the attitude of people without disabilities is inappropriate. The literature of the subject highlights the importance of socialisation processes, as well as other activities that organize the space for people with disabilities. At the same time, attention is drawn to the fact that treating differently people with disabilities in social life has an impact on "the content and manner in which disabled people fulfil their social roles, reduces their level of activity, depersonalises, transforms the sense of identity, self-esteem and self-image of a person, disturbs bonds and the degree of integration with the social environment” (Kubiak-Szymborska, 2012, p. 146).

Disabled people in the contemporary world are perceived from the angle of their limitations. A. Ostrowska (2003, p. 51) points out that there are various sorts of barriers - educational, health-related, architectural and employment, but mainly those that arise from wrong attitudes and stereotypes. Eliminating such obstacles is a necessary condition of active participation in social life of adult people with intellectual disabilities. Therefore, it becomes important to include this group of people in the process of establishing the rules of "being" in society rather than doing it without them. 


\section{METHODOLOGICAL ASSUMPTIONS}

People with intellectual disabilities are quite often treated as those who do not have their own identity, are not aware of their own being and their place in society. But nothing could be further from the truth. They understand their being in the world, they are able to comment on the social reality surrounding them and they are able to establish various relationships with members of the society without disabilities. Thus, when one plans research there is always hope that people with intellectual disabilities will allow for learning what is subjective and unique from the perspective of their experience. The research conducted for this paper has been founded on an interpretational approach, which - as J. Rzeźnicka-Krupa stresses - "with all its theoretical and methodological base, seems particularly suitable when we want to give an opportunity to speak to those who live on the margin of social life all the time” (2011, p. 74).

The aim of the study was to reconstruct the narratives and reach the subjective meanings that adult people with moderate intellectual disabilities impart on their participation in culture. The aspects of adult life of people with intellectual disabilities which are of interest to me can be studied in many ways, but I have used the biographical method in my research, considering it to be the most appropriate one. Owing to this method, "it is possible to reconstruct and interpret experiences in the biographies of adults with intellectual disability [...]” (Kijak, 2016, p. 122), which means getting to know an individual perspective of perceiving the world by study subjects. I was interested in the subjective senses and meanings given by adults to their own adulthood, but I also assumed that biography embraces a broader scope, because apart from the information about the respondents' lives, it allows us to see the specificity of their world, i.e., the "reflection of the general social patterns of meaning” (Segiet, 2013, p. 221). As a consequence of the use of the biographical method, I used narrative and biographical interview to collect empirical data, combining a narrative approach (Żyta, 2011). The use of an understanding narrative and biographical interview made it possible to obtain research material, i.e., statements of the respondents, constructed in relation to the research problem, which took the form of a question: How do people with moderate intellectual disabilities interpret their participation in culture?

My interlocutors are four adults with moderate intellectual disabilities, who quite often - as A. Żyta emphasizes - function "with the family” (2009, p. 89). This means that after completing their education they did not become independent, did not take up a job and, despite their age, they did not start their own family. Two of them (Paweł - aged 35, and Ewa - 43) take part in the Occupational Therapy 
Workshop, whereas the other two interviewees (Jola - 38, and Agnieszka - 45) do not work. All interviewees live in a family home with their parents (persons participating in the workshops live in an urban environment, while the other two live in a rural environment). I made contact with these people during interviews with their parents which I had conducted for another study. These meetings were held several times, so the conversations were not embarrassing for the interviewees. Moreover, it is important in qualitative research that they are based on a good rapport with the interviewees (Żyta, 2011, p. 28), especially if one touches on difficult, delicate or embarrassing issues during an interview. I conducted interviews in February 2018 with the consent of the interviewees and their parents (not all parents agreed to interviews, although the adults themselves wanted them very much). Therefore, the selection of samples was purposeful.

The analysis of the research material included biographical narratives of the respondents, which referred to the present and past subjective experience of the world of culture by adults with deeper intellectual disabilities.

\section{ANALYSIS OF THE NARRATIVES}

An analysis of the subjects' narratives revealed only rare cases of their direct interpretation of culture or their participation in it. In their stories, they talk about being cultural, that is, polite, well-mannered and nice to other people. However, they rarely talk about other forms of culture, such as going to the cinema, theatre, restaurant, or to a concert. In the narratives of people who participate in occupational therapy workshops, such form of culture are well known, but my feeling is that the interviewees, with strong attachment to their family environment, interpret culture through the lenses of family and its behaviour.

Ewa: "A cultural person is nice, pretty and polite. He/she doesn't make scenes, or things like that. [...] I'm cultural because I always say hello to neighbours and when I come to the workshops, I always say hello or good morning".

Jola: "[...] I think that culture is, for example, when you have a boyfriend and go on a date with him, for a coffee or to a restaurant - this is cultural".

Paweł: "Mr Andrzej always says that I'm cultural, because I always clean after I finish work and I always help in the kitchen, because I like it".

Agnieszka: "[...] I think that it is cultured when people behave themselves, they are nice to their guests [...] when someone comes to visit us I always offer coffee and it's nice". 
The interviewees also associate culture with leisure time. This is shown in the following passages:

Ewa: "Cultural people go for their holidays, and when they are on holidays, they drink beer or sunbathe. [...] and in the workshop we draw or make ourselves coffee and listen to music".

Pawel: "I think the point is that you can play football or ride a bike, because cultural people do pleasant things".

Agnieszka: "After work we sit on a bench outside the house, because all our neighbours sit outside after work. They are so decent because they don't drink beer or something”.

Culture is interpreted as responsibility, which - from the subjects' point of view - is equivalent to having a job. People who have a job are aware that work gives independence in various aspects of social life:

Paweł: “[...] a cultural person must work to have money because if he/she doesn't, he/she will not be cultural [...]. I am an adult, I go to the workshops and come back on my own [...]. This is my job because I make various things of clay there, such as bowls, moulded casts or small angels. Then we take it to a fair and people pay for these things [...]”.

Jola: “[...] an adult has to go to work, maybe he doesn't have to go somewhere, if he has his own farm, but this is the work of my parents, but I'd like to work somewhere in a shop, I'd sell nice clothes and then I'd have money, because now I help but I don't have my own money. Mum buys everything for me, but I'd like to do it myself [...]. If you have your own money you can feel like an adult and do everything. If I lived on my own, I'd put on a nice dress, because those which mum tells me to wear are childlike, and if I dressed nicely, I'd go to a shop or church on my own, because people go there nicely dressed [...]".

Ewa: “If I weren't an adult, I couldn't be at the workshop, because it's a job for people with disabilities [...] but I don't feel that I'm disabled, because disabled people have to be helped all the time, and I do everything myself. I like to work, because here I learn a lot of cool things and with Mrs. Jola we often go to the cinema, shop or for a walk. I don't want to have any other job, but maybe if I had another job then I would have more money and could live alone. I would be kind of independent [...]".

The narrators refer to their adulthood defined by the activities that they are unable to perform now. On the one hand, they are aware of their adulthood, and on the other - they have a feeling of being strongly restricted by their parents, with whom they live. This limitation applies to various spheres: friendly and intimate relationships, work, living and spending leisure time. The subjects do not define it as restriction of their participation in culture, but they have a feeling of loss. This is shown in the following passages:

Jola: “[...] because an adult can do what they want, talk to whom they want, go to work, dress in nice clothes and watch films for a long time. But sometimes when you 
live with your parents, you are no longer the same adult as without them, because parents know everything better and you have to listen to them".

Ewa: “[...] Mum does not allow me to go for a walk with my friend, or when my boyfriend comes, mum is with us all the time, and we would like to kiss, and if I lived alone, then nobody would disturb us, or even he could live with me. When adults get married, they already live together, so Maciek and I also have to get married and we will live together".

Pawel: "I'd like to do a lot of things because I'm an adult and I'm not that stupid; I can manage in life. But now, I'm such a mummy's boy”.

Starting a family is an attribute of adulthood as understood by the narrators. For them, it is a natural, "normal" stage which is accomplished in adulthood and which helps one to develop:

Jola: “[...] and I would have a husband to have a real family - my own and not my parents', because they're together and I don't have anyone, and I'm already old enough to have a husband. If I were not disabled, it would be so normal [...]”.

Pawel: "I'd like to have a wife and children, but my mother says I'm disabled and, well, that's why I can't have it, but I'd like to. I would be a good husband [...]”.

Ewa: "I have a fiancé, but my mother doesn't let me meet him. He is with me at the workshop, we sit next to each other, he makes me coffee in the morning, I know he loves me. I love him too, but my mother doesn't let me talk about him at home. Then she is very sad, and I don't want her to be sad. I often cry when I miss him, because sometimes I can't go to the workshops, he certainly misses me too. I'd like him to become my husband, we are adults, but my mother doesn't agree [...]”.

An analysis of the narratives shows the interviewees who not only are selfaware of their disability, but they are also confident of their agency and ability to make decisions as adults, which will make their lives "better":

Agnieszka: "[...] I can cope with various things at the same time, because I have to clean up, cook dinner, take care of the farmstead. I do everything myself, when my mother and brother are in the field, nobody helps me, and everything is done".

Ewa: "[...] although I don't feel that I'm disabled, because the disabled must be constantly helped, and I do everything myself. I've learnt a lot at the workshops, because at home I only watch television, and at the workshops we do the shopping ourselves, prepare meals, make embroidered things [...]. If I'm on my own, I will certainly manage it all, because Mrs. Jola says that I'm very independent”.

Pawel: "I know when to do what in front of the building. I go to the manager and say that this and that must be done and he says that it's good that I think about everything and that I should do it. I decide for myself what to do first, because I know my job”.

Jola: “[...] I think my life would be better if I lived on my own, because now I don’t have a life".

In their statements, the narrators construct their dreams, which are not farreaching. They concern everyday matters, even banal ones at times, but ones which are important from their perspective. These fragments of the narrative show that 
the subjects would like to participate in culture, although they are not fully aware of how to define culture:

Jola: "And mum has me wear such clothes that when I walk by a school, they laugh at me. I don't want to wear these hair pins, but mum thinks I'm her little daughter. I'd like to decide what to wear and let down my hair, maybe put on a little make-up, but only very delicately".

Pawel: "I have a lot of dreams, like everyone else, but the greatest one is to have a driving licence and a car. Now I get to the workshops by bus, and if I had a car, I would drive and I'd take my colleagues too".

Agnieszka: "[...] My friends, they also go shopping to town, they go to have fun and on Sunday they walk around the village [...]. I'd also like to go for walks with them or to town, but there's always work to be done at the farm and mum tells me to stay at home".

Ewa: "My colleague is in a nursing home and she is very happy. The home is not far away. I also want to live there, I could do things like drawing or cut-outs. I also like dancing and singing. I could walk holding hands with my boyfriend [...] but these are only such dreams, because my mother says that her heart would burst if I went to live there".

\section{CONCLUSION}

An analysis of the narratives shows the world of disabled people who interpret culture subjectively. Narrators impart individual sense and meaning to culture, which shows "the truth" about participation in it. They rarely refer to culture itself, rather talk about their adult lives. But these fragments of their narratives are full of information about their participation in culture, although they do not see it and they do not define it in this way. They perceive culture as good behaviour, spending free time or duties related to adulthood, such as finding a job or starting a family.

The presence of their parents in the subjects' lives is strongly emphasised; it affects the reality the narrators live in and, in consequence, their participation in culture. The adulthood of these people is dominated by their parents because of their living together. The narrators themselves notice it; they point to significant events in their lives, which could have taken a completely different course if it had not been for the intervention of their parents. The narratives show that the adult life of these people, and thus their participation in culture outside the family, is severely limited. I am under the impression that the narrators are aware that their parents' overprotectiveness inhibits their development and restricts their participation in social life. They have a feeling of loss and they say that their lives could be "better". 
Their parents limit them in many ways. Such limitations apply to various spheres: clothes, accommodation, work, relationships and leisure time. In short, adults with intellectual disabilities who live with their parents do not realise their adulthood to the extent that they would want to. This means that the subjects participate in a culture popularised by the family, but their parents' attitudes towards them means that using other cultural influences is supervised and controlled. This results in a limited number of roles for the narrators, or the impossibility of performing some of them, for example, being a mother or a father. Relations with others are limited to professional life, because the sphere of friendship or even intimate relationships is under strict control. Their social life and leisure time are dominated by their parents' needs rather than those of adult people who wish to meet their friends and pursue their passions outside their home.

Living with their parents has made intellectually disabled adult people grow into the culture of their parents and local communities. They adopted the habits, traditions and customs of their family homes, but they are aware of their adulthood and they also want to "live" outside the family. The narrators know that there are other forms of culture, such as discos, trips to town, doing shopping, time spent with friends, etc., and they would like to take advantage of the privilege of their age. However, this is prevented by overprotective parents, who control and limit each manifestation of their initiative and independence. An analysis of the narratives may leave one under the impression that the narrators are confident that they would be much better off if they did not live with their parents. Parental overprotection, their excessive care and anxiety limit adulthood and, as a consequence, their adult offspring's ability to develop. Lack of autonomy in adult life results in a low level of participation in culture. The interviewees are distinctly aware of this, because their plans for the future or dreams relate to full and active participation in the life of the society. Another reason for limited participation in culture are the respondents themselves, who are aware that they are treated by their parents as immature children. This results in a sense of shame and partial withdrawal from social life.

The narratives of the participants of the occupational therapy workshops are different, because apart from their vocational education, they also take part in various training sessions: interpersonal, economic or social, during which they learn how to behave in public places. In their stories, they mention going to the cinema, to a shop or for a walk, but they also mention relationships outside the workshop, which become intimate ones. The biographies of these narrators also strongly emphasize the interference of parents, which results in severe restriction of any manifestations of out-of-family activities. 
Participation in the culture of adults with moderate intellectual disabilities in culture is very limited due to numerous barriers, especially those of a mental nature. The main source of such limitation are the parents, which suppress independence, decision-making, agency, willingness to develop, and active participation in social life. The narrators are very open to the "new", which fascinates them and, for the time being, remains within the sphere of their dreams. During the time they live together with their parents, they mainly move in the local cultural environment, which for them as adults is no longer attractive and can be a source of frustration rather than a place of development. One should also remember about the limitations resulting from the disability itself, which the narrators are not aware of. The reduced intellectual potential causes some difficulties in the orientation of this group of people in such a complicated social reality.

\section{References}

Bauman, Z. (2012). Kultura jako praxis. Warszawa: PWN.

Błeszyńska, K. (2012). Niepełnosprawność a struktura identyfikacji społecznych. Warszawa: Żak. After: Kubiak-Szymborska, E. (2012). Podmiotowość: o szansach i możliwościach rozwoju. In: R.J. Kijak (Ed.),Niepełnosprawność - w zwierciadle dorosłości (pp. 135152). Kraków: Oficyna Wydawnicza "Impuls".

Borzyszkowska, H. (1997). Izolacja społeczna rodzin majq̨cych dziecko upośledzone umysłowo w stopniu lekkim. Gdańsk: Wydawnictwo UG.

Cytowska, B. (2012). Trudne drogi adaptacji. Wqtki emancypacyjne w analizie sytuacji dorosłych osób z niepełnosprawnościq intelektualnq we współczesnym społeczeństwie polskim. Kraków: Oficyna Wydawnicza "Impuls".

Fleischer, M. (2002). Teoria kultury i komunikacji. Systemowe i ewolucyjne podstawy. Wrocław: Dolnośląska Szkoła Wyższa TWP.

Giddens, A. (2002). Nowoczesność i tożsamość "Ja” i społeczeństwo w epoce późnej nowoczesności. Warszawa: PWN.

Giddens, A. (2012). Socjologia. Warszawa: PWN.

Godzic, W. (2013). Kuba i inni. Twarze i maski popkultury. Warszawa: Wydawnictwo Akademickie Sedno.

Golka, M. (2008). Socjologia kultury. Warszawa: Wydawnictwo Naukowe "Scholar".

Goodman, N. (1997). Wstęp do socjologii. Poznań: Wydawnictwo Zysk i S-ka.

Gruchoła, M. (2010). Kultura w ujęciu socjologicznym. Roczniki Kulturoznawcze, 1, pp. 95-114.

Hall, E.T. (2001). Poza kulturq. Warszawa: PWN.

Jabłoński, D., \& Ostasz, L. (2001). Zarys wiedzy o rodzinie, małżeństwie, kohabitacji i konkubinacie. Perspektywa antropologii kulturowej i ogólnej. Olsztyn: Wydawnictwo Adiaphora.

Jakubowski, W. (2017). Wstęp. In: Pedagogika kultury popularnej - teorie, metody i obszary badań (pp. 9-12). Kraków: Oficyna Wydawnicza "Impuls". 
Kawula, S. (2009). Mozaikowość i koloryt współczesnej rodziny. Szkic do portretu. In: S. Kawula, J. Brągiel, \& A.W. Janke, Pedagogika rodziny. Obszary i panorama problematyki (pp. 359-391). Toruń: Wydawnictwo Adam Marszałek.

Kijak, R. (2016). Dorośli z głębszq niepełnosprawnościq intelektualnq jako partnerzy, małżonkowie i rodzice. Kraków: Wydawnictwo Naukowe UP.

Konarzewski, K. (1994). Wzory kultury a indywidualność. In: J. Brzeziński, \& L. Witkowski (Eds.), Edukacja wobec zmiany społecznej (pp. 368-376). Poznań-Toruń: Wydawnictwo "Edytor".

Kościelska, M. (2003). Odpowiedzialni rodzice. Z doświadczeń psychologa. Kraków: Oficyna Wydawnicza "Impuls".

Krause, A. (2010). Współczesne paradygmaty pedagogiki specjalnej. Kraków: Oficyna Wydawnicza "Impuls".

Kwiatkowska, G.E., \& Siudem, A. (Eds). (2014). Człowiek w środowisku kulturowym. Lublin: Wydawnictwo UMSC.

Lach-Rosocha, J. (2006). Rola kultury w procesie uczłowieczania człowieka i humanizacji świata - wybrane aspekty problemu. In: D. Kubinowski (Ed.), Kultura współczesna a wychowanie człowieka (pp. 88-98). Lublin: Wydawnictwo Verba.

Molesztak, A.M. (2015). Człowiek. Kultura. Uczestnictwo. Bydgoszcz: Wydawnictwo UKW.

Ostrouch-Kamińska, J. (2015). Rodzina partnerska jako relacja współzależnych podmiotów. Studium socjopedagogiczne narracji rodziców przeciqż̇onych rolami. 2nd Ed. Kraków: Oficyna Wydawnicza "Impuls”.

Ostrowska, A. (2003). Kompetencje społeczne osób niepełnosprawnych - bariery dorosłości. In: K.D. Rzedzicka, \& A. Kobylańska (Eds.), Dorosłość, niepełnosprawność, czas współczesny. Na pograniczach pedagogiki specjalnej (pp. 51-60). Kraków: Oficyna Wydawnicza "Impuls".

Pankowska, K. (2013). Kultura - sztuka-edukacja w świecie zmian. Refleksje antropologicznopedagogiczne. Warszawa: Wydawnictwo UW.

Rzeźnicka-Krupa, J. (2011). Niepełnosprawność i świat społeczny. Szkice metodologiczne. Kraków: Oficyna Wydawnicza "Impuls”.

Segiet, W. (2013). O zwiqzzu edukacji z rodzinq. Społeczne konteksty i jednostkowe biografie. Poznań: Wydawnictwo Naukowe UAM.

Szczurek-Boruta, A. (2006). Kultura - społeczeństwo - jednostka: zaniedbane i zaniechane obszary edukacji szkolnej. In: D. Kubinowski (Ed.), Kultura współczesna a wychowanie człowieka (pp. 158-165). Lublin: Wydawnictwo Verba.

Sztompka, P. (2002). Socjologia. Kraków: Wydawnictwo Znak.

Świtaj, P. (2008). Doświadczenie piętna społecznego i dyskryminacji u pacjentów z rozpoznaniem schizofrenii. Warszawa: Instytut Psychiatrii i Neurologii.

Wiatr, M. (2008). Rodzicielstwo społecznie naznaczone - stygmatyzacja rodzin z dzieckiem niepełnosprawnym. Człowiek - Niepełnosprawność - Społeczeństwo, 1, pp. 69-84.

Wrona, S. (2016). Wsparcie rodziny z dzieckiem niepełnosprawnym w procesie wczesnej interwencji - wątek zaniedbany. Niepełnosprawność, 24, pp. 212-221.

Żółkowska, T. (2003). Wartościowanie pojęcia “dorosłość” przez osoby niepełnosprawne intelektualnie. In: K.D. Rzedzicka, \& A. Kobylańska (Eds.), Dorosłość, niepełnosprawność, czas współczesny. Na pograniczach pedagogiki specjalnej (pp. 239-251). Kraków: Oficyna Wydawnicza "Impuls”. 
Żyta, A. (2009). Dorosłość osób z niepełnosprawnością intelektualną w województwie warmińsko-mazurskim. Ograniczenia i możliwości w świetle relacji społecznych. Niepełnosprawność, 2, pp. 85-92. DOI: DOI: 10.13140/RG.2.1.2278.0323.

Żyta, A. (2011). Życie z zespołem Downa. Narracje biograficzne rodziców, rodzeństwa i dorosłych osób z Zespołem Downa. Kraków: Oficyna Wydawnicza “Impuls”. 